\author{
Anna Odrowąż-Coates \\ Anna Perkowska-KLejman
}

\title{
The English language as a reflective judgement component in the intercultural Erasmus exchange to and from Poland
}

\begin{abstract}
In the empirical study of intercultural exchange presented in this paper, we assessed Erasmus students for knowledge of English as a foreign language $(\mathrm{EFL})$ and their level of reflective judgement, to test for correlation between the two variables. The basic theoretical framing was derived from King and Kitchener's (1994) reflective judgment model (RJM), based on 3 different levels of reflectivity, connected to progressive cognitive development of adults: pre-reflective, quasireflective and reflective. The results of the study show that the students displayed high levels of reflective judgment and importantly, we found a correlation between their standard of English and their level of reflectivity. The ability to communicate in English is a prerequisite to participation in the Erasmus programme, therefore it was expected that the students would score well for English knowledge. However, the results of the study suggest that being competent in the use of English as a foreign language may be a predictor of higher reflectivity amongst students in higher education. This creates a controversial pedagogical implication suggesting that learning English as a foreign language to a high standard fuels reflectivity.
\end{abstract}

Keywords: reflective judgement, English as a foreign language, EFL, higher education, Erasmus, study abroad

\section{Introduction}

A comprehensive review of programmes for students to study abroad was carried out by Tullock and Ortega (2017) using over 400 study materials from 1995-2017. They established that the evidence on linguistic gains expected from studying a language abroad is inconclusive, incidental and often leads to conflicting results. Nevertheless, a range of coexisting social, professional and personal benefits continue to be a major selling point for students who are considering opportunities to study L2 abroad. In 2018 over 2 million students took part in the Erasmus exchange in 34 participating countries (Erasmus + key figures 2018). 
In Spring 2020 many Erasmus exchange activities were temporarily frozen due to the COVID-19 pandemic in Europe (Erasmus + 2020). Some exchange students returned to their home countries, others remained in their host country and continued to benefit from the activating learning environment of a foreign exchange. The activating learning environment can be described by the complex dynamic systems theory (Han, 2019) that supports the idea that learners progress relies on the interplay of initial conditions, interconnectedness, unpredictability, adaptability, and complexity of the learners' first language. The above conditions, especially unpredictability, adaptability and complexity are the exact preconditions for activation of reflective thinking. In a former study by Serrano et al. (2011), Spanish students exposed to L2 in the context of Erasmus exchange to the UK outperformed those attending intense courses at home country in fluency and lexical complexity. Moreover, the study by Dao (2020) on peer interaction in effective learner engagement, indicate that there is indeed a high benefit in participation in activating learning environments, where peers can exchange their ideas with one another. It has been observed that this condition occurs spontaneously and naturally in Erasmus exchange groups.

Commencing our study, we wanted to test whether Erasmus students are individuals capable of reflective judgment at the highest level. Erasmus exchange students are expected to communicate in English as it is considered the Lingua Franca of European academia. We therefore decided to assess their knowledge of English as a foreign language, and to look for links between their reflectivity and the language aspect. We wanted to discover whether knowledge of English as a foreign language correlates with levels of reflectivity. If we were to find a positive correlation this could mean that achieving high standard of EFL triggers high levels of reflective judgement. Further studies would have to verify if this is a phenomenon related to English language in particular, or to any other foreign language taught as a first foreign language of a person. Nevertheless, it would add to the list of benefits/pros for the EFL learning.

\section{Background}

\subsection{Erasmus exchange programme - an overview of the outcomes}

In the context of multicultural and intercultural exchanges, positive intergroup relations formed due to study abroad programmes were found by Pet- 
tigrew (1998), Gaertner and Dovidio (2000); Kennworthy et al. (2005). According to Stroebe et al. (1988), Stangor et al. (1996) and Ward et al., (2001) the exchange programmes decrease stereotypes about other nationalities, eradicate prejudice and 'othering' of other ethnic groups. Furthermore, they confirm that exchanges enhance critical thinking and accept the diversity of opinions and worldviews (c.f. Odrowąż-Coates 2017). The above features gained through the exchange programmes are in line with the higher level of reflective judgement. Could this be aided by the knowledge of the 'common' foreign language that creates a platform for cultural exchanges, situating conversation participants at similar linguistic advantage-disadvantage situation? Structural aspects of the English language acquisition as depicted by Odrowąż-Coates (2019) may dictate an equal ground for the Erasmus exchange participants from non-English speaking countries.

English language has become the Lingua Franca of Erasmus programme exchanges (c.f. Kalocsai, 2009, Kaypak and Ortaçtepe 2014, Llanes et al., 2016). Erasmus is the largest programme for student mobility ever developed in Europe. It involves the exchange of experiences, knowledge, information, worldviews and values. For the majority of beneficiaries, the exchange lasts one semester (EC 2019). Erasmus is meant to improve the quality of higher education in Europe on policy level (system), institutional level, and individual level. To date, the largest study of measurable effects of the Erasmus programme was carried out by "CHE Consult" (ESN 2012). The study involved 75 thousand students and graduates from 43 countries. The survey revealed the shared, personal traits of participants regarding reflectivity factors, such as problem-solving capacity, openness to challenges and change, curiosity and acceptance of values and behaviours of other people. Features such as entrepreneurship, creativity, curiosity, vitality and openness to ambiguity were confirmed in another study (EACEA 2014).

\subsection{The reflective judgment model - research theory}

The theoretical basis for the model of reflective judgment may be found in classical studies of human cognition by Piaget or Kohlberg and several concepts aiming to explain cognitive and social functioning of humans (c.f. Dewey, 1933; Flavell, 1976; Perry, 1981; Broughton, 1978; Fischer, 1980; Kegan 1982; King et al. Wood 1983). The reflective judgement model consists of three levels describing how the knowledge is gained and how the opinions about the best course of action are justified: pre-reflective, quasi reflective 
and reflective positioned in hierarchical order and gained in more and more advanced stages (King and Kitchener 2002). Figure 1 depicts the multiple levels of reflective judgement. It shows the connection between need for reflectivity when dealing with complex, difficult questions or problems that may possess many solutions. The precise description of the model and the research procedure is described in Odrowaz-Coates, Perkowska-Klejman (2017), as the model and the research procedure was successfully replicated.

Figure 1. Summary of reflective judgment stages - cognitive assumptions, well-structured and ill-structured problems and the levels of reflective judgment (adapted from King and Kitchener, 1994, 2002).

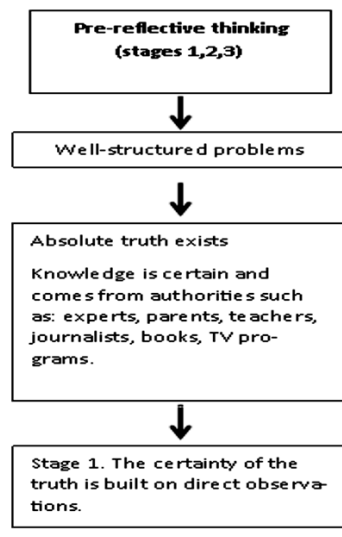

Stage 2.

Solution to a problem may be temporarily absent but necessary knowledge may be always gained some how dire ctly or indire ctly

Stage 3 .

There may be a temporary uncertainty of knowledge, but it is quickly counte racted

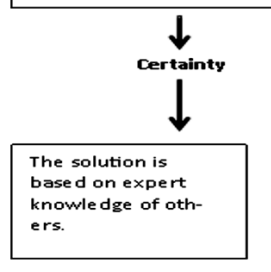

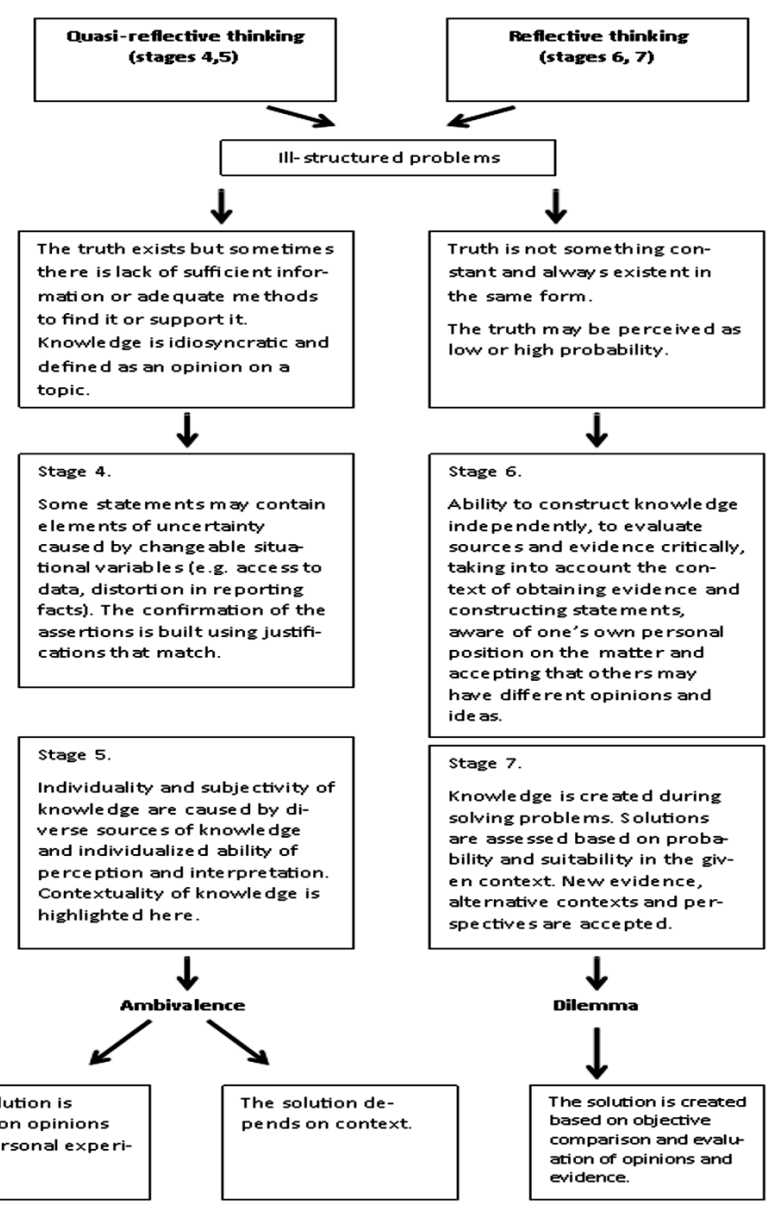




\section{Methodology}

\subsection{Research questions}

The research addresses the following questions:

- What is the level of reflective judgment amongst international Erasmus exchange students?

- Is their age, gender or level of study interlinked with their level of reflective judgement?

And finally, we posed the main research question:

- Are EFL skills interlinked with the level of reflective judgment?

\subsection{Research design and context}

The main aim of the empirical study was to establish the level of reflective judgment (RJ) amongst Erasmus exchange students and to test whether there may be a link between RJ and EFL skills. Although "System" has released a significant number of articles dedicated to reflectivity as an educational category, found in the process of learning and teaching, sometimes identified as reflexive thinking or reflexivity, and a few papers dedicated to study abroad $(\mathrm{SA}=$ study abroad $)$ programmes, the authors did not find any previous attempts to measure reflectivity of Erasmus students. RJ has remained a subject of study by many social scientists in the last 25 years.

Many studies confirm that reflective thinking is a developmental category, diversified by the level of study and the age of research participants (e.g.: King and Kitchener, 2002; Boyd, 2008; Fischer and Pruyne, 2002). King and Kitchener (1994) suggested that formal operations, academic ability, critical thinking and verbal aptitude are directly connected to the level of reflective judgement. Guthrie, King and Palmer (2000) found that development of reflective judgement is a strong predictor of tolerance for diversity and identity development and Odrowąż-Coates (2019) suggested that people with less conservative views are more likely to improve their foreign language skills abroad. The authors of this empirical enquiry, established in a preliminary study that reflective judgement is diversified by the subject studied (Perkowska-Klejman, 2018), therefore the sample of participants was purposely selected in order to reflect diverse fields of studies. Our study had an explorative and not a confirmative character in the areas of foreign language skills 
and the socio-cultural factors, so no presumptions were made in this respect.

\subsection{Limitations}

We realise that there are several limitations for the development of a more general theory. Firstly, there was no perfectly matched control group. We relied on the results of several previous studies of reflectivity amongst higher education students, which were carried out over the last 5 years (c.f., Perkowska-Klejman, 2014; Perkowska-Klejman, 2018; Odroważ-Coates, Perkowska-Klejman, 2019). Secondly, there was no clear indication found to show if participation in the Erasmus programme develops the competence of reflective judgment and to what extent it is already developed as a result of education in the country of origin. The same applies to foreign language acquisition, as we were unable to test the participants before they attended the Erasmus programme.

Moreover, the research was conducted in English. This language-based exclusionary practice poses additional problems for representation (c.f. Odrowąż-Coates 2019). In this vein, a small number of questionnaires were not suitable for analysis and were not included in the sample due to a lack of English language skills displayed by a few participants. Notwithstanding these limitations, the answers given by the participants allowed us to run the language skill assessment, which was then cross-evaluated with the participants' self-declared EFL skills. In this sample the self-declared and the actual written level of English were highly coherent, indicating high self-reflectivity. Even though only those with sufficient EFL skills were able to participate, the data supports the purpose of the study, enabling us to measure the level of reflectivity amongst this particular, linguistically privileged group of students.

\subsection{The reflective judgment interview}

The measuring of reflective judgment was carried out using a written version of The Reflective Judgment Interview (King and Kitchener, 1994). It is a semistructured interview, containing specific descriptions of five cognitively ambiguous problems with several additional questions. Psychometric values of both orally conducted (Cronbach's alpha ranging from .75 to .96) (Wood, Kadrash, 2002) and the written version of the interview questionnaire are high (Cronbach's alpha $=.85$ ) (Perkowska-Klejman, 2018) so both methods 
are confirmed as valid. An example of one of the five statements used in this Reflective Judgment Interview (ill-structured problem with additional questions) is as follows:

Ill-structured problem: The safety of nuclear energy is currently being debated by scientists in many fields. Some scientists believe that nuclear energy is safe and that nuclear energy can substantially alleviate our dependence on non-renewable resources. Others argue that nuclear energy is inherently unsafe and that nuclear energy plants will lead to widespread and long-term environmental pollution.

Additional questions:

- What do you think about this statement?

- How did you come to hold that point of view? On what do you base that point of view?

- Can you ever know for sure that your position on this issue is correct? How or why not?

- When two people differ about matters such as this, is it the case that one opinion is right and one is wrong? If yes, what do you mean by "right"? If no, can you say that one opinion is in some way better than the other?

- What do you mean by "better"?

- How is it possible that people have such different views about this subject?

- How is it possible that experts in the field disagree about this subject?

Every interview questionnaire filled in by the research participants was individually analysed to assess the level of reflective judgement on a scale 1-7 by two independent judges from outside of the research team. The final level of reflective judgement was presented using the arithmetic mean. This allowed us to carry out statistical analysis of the qualitative RJ questionnaire answers. The interview questionnaire also contained a short, anonymous demographic section and a linguistic self-assessment.

\subsection{Participants}

The study took place between January 2018 and October 2019, it included 125 Erasmus exchange students from and to Poland. Those visiting Poland were from the following European countries: Albania, Belgium, Bulgaria, Czech Republic, Denmark, France, Greece, Germany, Hungary, Italy, Netherlands, Portugal, Slovenia, Spain, Sweden, Turkey. It should be noted that due 
to the criteria used for selection, students who took part in the study were already immersed in the international learning environment and had been abroad between 2 and 4 months by the time of the interview. The snowball method was used to attract new willing research participants. This method used the internet and relied on participants recommending other Erasmus exchange students who may be interested in taking part in the study during their stay abroad. The researched group was diverse in terms of nationality, age, educational level and the subject of study; there was no control group selected. However, the comparison with multiple previous study results on reflectivity of Polish students, who were studying in Poland, carried out by Perkowska-Klejman (2014, 2018), and Perkowska-Klejman, Odrowaz-Coates (2019), show that the level of reflectivity was (on average) higher in the Erasmus exchange sample than in the general domestic one.

\section{Research results}

\subsection{The overall level of reflective judgement amongst Erasmus exchange students}

The overall median amongst Erasmus students, based on the model of reflective judgement was $\mathrm{M}=4.65(\mathrm{SD}=1.03$, $\min =2.6$; $\max =6.60)$. This is a relatively high median score, when compared to other studies of students in higher education who are not exposed to SA programmes (c.f. PerkowskaKlejman and Odrowąż-Coates 2019).

\subsection{Gender, age and level of study and the level of reflective judg- ment}

The results presented in table number 1 show no significant difference for reflective judgment when gender is considered, using median comparison ( $t$ test). Furthermore, the single factor ANOVA results are presented, showing strong correlation between age, level of studies and RJ. The age and level of study results are masked and therefore we run additional tests not shown in the table. When we tested correlation between reflective judgement level and two independent variables at the same time (age range and the level of studies), we received a corrected multifactorial ANOVA model for analysis of variance with $\mathrm{F}=2.78(\mathrm{p}=.02)$. When these variables were tested individually against $\mathrm{RJ}$, the connection between the level of studies and reflective judgment was weak 
$\mathrm{F}=.50(\mathrm{p}=.47)$ and the age range variable when tested on its own against $\mathrm{RJ}$ was also not statistically relevant $\mathrm{F}=2.21(\mathrm{p}=.71)$. The tests were repeated, but with the age variable not grouped into age range. When we tested level of study and the age variable (not grouped into age range) against RJ, the Corrected Model showed a connection $\mathrm{F}=2.48(\mathrm{p}<.01)$. However, when these two new groups of data were tested separately against RJ, $\mathrm{F}$ for the level of studies in this second model had no statistical validity $\mathrm{F}=.04(\mathrm{p}=.52)$ but the age did $\mathrm{F}=2.15(\mathrm{p}=.01)$. This result suggests that individual age is a diversifying factor of reflective judgment. In our research group, 10 participants were over 30 and all of them displayed high levels of reflective judgment, with $\mathrm{M}$ between 5.2 and 6. Whilst results for 20-22 years old were at $M=4.5$.

Table 1. Gender, age and level of study and the level of reflective judgment

\begin{tabular}{|l|c|c|}
\hline \multicolumn{1}{|c|}{ Variable } & M (SD) & Statistical test results \\
\hline Gender & & $\mathrm{t}=.92(\mathrm{p}=.35)$ \\
\hline Male $(\mathrm{n}=31)$ & $4.66(1.02)$ & \\
Female $(\mathrm{n}=96)$ & $4.46(1.03)$ & \\
\hline Age (years) & & $\mathrm{F}=3.35(\mathrm{p}=.01)$ \\
\hline $18-19(\mathrm{n}=2)$ & $4.3(.70)$ & \\
$20-21(\mathrm{n}=46)$ & $4.22(.04)$ & \\
$22-23(\mathrm{n}=41)$ & $4.78(1.09)$ & \\
$24-25(\mathrm{n}=24)$ & $5.28(.92)$ & $\mathrm{F}=4.99(\mathrm{p}<.01)$ \\
26 and above $(\mathrm{n}=14)$ & & \\
\hline Level of study & $4.53(1.07)$ & \\
\hline Bachelor $(\mathrm{n}=75)$ & $4.58(.99)$ & \\
Master $(\mathrm{n}=42)$ & $5.72(.38)$ & \\
Doctoral $(\mathrm{n}=8)$ & &
\end{tabular}

Source: Self generated

\subsection{Foreign language skills, exposure to study abroad environment and the level of reflective judgment}

As shown in the table above (Table 2), in our sample, we found no connection between level of reflective judgement and previous studies or stays abroad as an adult and no connection between the level of the second foreign language and the reflective judgement level. However, we found connection between EFL skills and reflective judgment levels. There was a weak statistical correlation between level of reflective judgement and having been abroad as a child, and a stronger connection between level of reflective judgement and the level of English as a foreign language. The results were indicative of tendency to link EFL skills with reflective judgement and vice versa. 
Table 2. The level of reflective judgment M(SD), SA and the foreign language skills

\begin{tabular}{|c|c|c|}
\hline & M (SD) & Statistical test results \\
\hline $\begin{array}{l}\text { Previous stays abroad (as a child) } \\
\text { Yes }(\mathrm{n}=58) \\
\text { No }(\mathrm{n}=69)\end{array}$ & $\begin{array}{l}4.80(1.05) \\
4.45(1.02)\end{array}$ & $\mathrm{t}=1.87(\mathrm{p}=.06)$ \\
\hline \multicolumn{3}{|l|}{ Previous stays abroad (as an adult) } \\
\hline $\begin{array}{l}\text { Yes }(\mathrm{n}=112) \\
\text { No }(\mathrm{n}=15)\end{array}$ & $\begin{array}{l}4.60(1.05) \\
4.73(1.03)\end{array}$ & $\mathrm{t}=.46(\mathrm{p}=.64)$ \\
\hline \multicolumn{3}{|l|}{ Previous studies abroad } \\
\hline $\begin{array}{l}\text { Yes }(\mathrm{n}=16) \\
\text { No }(\mathrm{n}=111)\end{array}$ & $\begin{array}{l}4.35(1.03) \\
4.65(1.04)\end{array}$ & $\mathrm{t}=1.08(\mathrm{p}=.27)$ \\
\hline \multicolumn{3}{|l|}{ FL skills in multiple languages } \\
\hline $\begin{array}{l}1 \text { foreign language }(n=63) \\
2 \text { foreign languages }(n=61) \\
3 \text { foreign languages }(n=3)\end{array}$ & $\begin{array}{l}4.57(1.14) \\
4.66(.95) \\
4.33(.98)\end{array}$ & $\mathrm{F}=.22(\mathrm{p}=.79)$ \\
\hline \multicolumn{3}{|l|}{ Level of English } \\
\hline $\begin{array}{l}\text { just a few words }(\mathrm{n}=0) \\
\text { poor }(\mathrm{n}=0) \\
\text { communicative }(\mathrm{n}=22) \\
\text { good }(\mathrm{n}=62) \\
\text { excellent }(\mathrm{n}=42) \\
\text { native tongue }(\mathrm{n}=1)\end{array}$ & $\begin{array}{c}4.17(1.15) \\
4.57(1.09) \\
4.90(.83) \\
5.00\end{array}$ & $\mathrm{~F}=2.50(\mathrm{p}=.06)$ \\
\hline \multicolumn{3}{|l|}{ Level of second foreign language } \\
\hline $\begin{array}{l}\text { just a few words }(\mathrm{n}=2) \\
\text { poor }(\mathrm{n}=21) \\
\text { communicative }(\mathrm{n}=24) \\
\text { good }(\mathrm{n}=11) \\
\text { excellent }(\mathrm{n}=8) \\
\text { native tongue }(\mathrm{n}=0) \\
\end{array}$ & $\begin{array}{l}4.10(.98) \\
4.80(.82) \\
4.59(.94) \\
4.47(1.09) \\
5.07(1.08)\end{array}$ & $\mathrm{F}=.79(\mathrm{p}=.53)$ \\
\hline
\end{tabular}

Source: Self generated.

\section{Discussion and conclusions}

The results of the study confirm that the experience of studying abroad is associated with high reflectivity. Furthermore, a link between the level of reflective judgement and the level of EFL skills was verified. Also confirmed were similar links between the reflective judgment level and the age of participants, and between their exposure to a foreign language environment in childhood. A new question emerged. Are the more fluent users of EFL capable of expressing deeper and more elaborated comments in the RJQ? Could it be that they scored higher on the reflectivity scale simply due to their linguistic superiority? Even if this were the case (although, based on the RJQ evaluation we believe it wasn't), it highlights that the EFL level is a significant factor for equality of participation and equality of opportunity. Since all Erasmus exchange students 
scored relatively high on the reflectivity scale, it demonstrates that participants of the Erasmus programme are in general more reflective that non-participants (c.f. Perkowska-Klejman 2014, 2018, Perkowska-Klejman\&Odrowaz-Coates 2019). However, it is not possible to confirm whether they were already more reflective before participating in the programme or if the programme itself enhances their reflectivity. Entry criteria related to EFL level indicate that EFL users may be in general more reflective. Further studies in this area are necessary to continue testing this hypothesis.

\section{Funding}

Grant number: APS BSTP 5/18-I "How to solve difficult cognitive problems? Reflectivity amongst Erasmus exchange students." Ministry of Science and Higher Education (Poland), Statutory Research Activity @ The Maria Grzegorzewska University.

\section{Bibliography}

Badanie wptywu programu Erasmus 2018. Research of Erasmus Programme Influence. https://issuu.com/frse/docs/erasmus_impact_study_pl (14.10.2019).

Bauman, Z. 2000. Liquid modernity. Cambridge: Polity Press.

Ballatore, M. and Ferede, M. 2013. The Erasmus Programme in France, Italy and the United Kingdom: Student Mobility as a Signal of Distinction and Privilege. European Educational Research Journal. 12 (4), pp. 525-533.

Boyd, L.D. 2008. Development of reflective judgement in the pre-doctoral dental clinical curriculum. European Journal of Dental Education. 12, pp. 149-158 .

Broughton, J. 1978. The development of concepts of self, mind, reality, and knowledge. New Directions for Child Development. 1, pp. 75-100.

Dao, P. 2020. Effect of interaction strategy instruction on learner engagement in peer interaction, System, 91, https://doi.org/10.1016/j.system. 2020.102244.

Dewey, J. 1933. How we think. Boston, MA: D.C. Heath \& Co Publishers.

EACEA 2014. The Erasmus Impact Study. https://eacea.ec.europa.eu/sites/ eacea-site/files/erasmus-impact_en.pdf (14.10.2019).

EC 2019. Erasmus+: a turning point in the lives of 5 million European students. https://ec.europa.eu/programmes/erasmus-plus/news/erasmusimpact-studies_en (11.10.2019). 
ESN 2012. The Erasmus Impact Study, Effects of mobility on the skills and employability of students and the internationalization of higher education institutions. https://esn.org/erasmus-impact-study (14.10.2019).

European Commission 2013. Report to the European Commission on Improving the quality of teaching and learning in Europe's higher education institutions. Luxembourg: Publications Office of the European Union.

Erasmus+ Key figures 2018. https://ec.europa.eu/programmes/erasmus-plus/ about/key-figures_en Accessed (14.10.2019).

Erasmus+ 2020. Coronavirus - essential practical advice on Erasmus+ and European Solidarity Corps mobility https://ec.europa.eu/programmes/ erasmus-plus/resources/coronavirus-practical-factsheet_en (26.05.2020).

Fischer, K.W. 1980. A Theory of Cognitive Development: The Control and Construction of Hierarchies of Skills. Psychological Review. 87 (6), pp. 477$-531$.

Fischer, K.W. and Pruyne, E. 2002. Reflective thinking in adulthood: Emergence, development, and variation. In: Demick, J. and Andreoletti, C. eds. The Handbook of Adult Development. New York: Plenum, pp. 169-198.

Flavell, J.H. 1976. Metacognitive aspects of problem solving. In: Resnick, L.B. eds. The nature of intelligence. Hillsdale, NJ: Lawrence Erlbaum, pp. 231-235 .

Gaertner, S. and Dovidio, J. 2000. Reducing Intergroup Bias. Philadelphia, PA: Psychology Press.

Guthrie, V.L., King, P.M. and Palmer, C.J. 2000. Cognitive capabilities underlying tolerance for diversity among college students. https://www.diversityweb.org/digest/sp (14.05.2019).

Han, Z. 2019. Profiling learner language as a dynamic system. Clevedon: Multilingual Matters.

Kalocsai, K. 2009. Erasmus exchange students: A behind-the-scenes view into an ELF community of practice. Journal of Applied Language Studies. 3 (1), pp. 25-49.

Kaypak, E. and Ortaçtepe, D. 2014. Language learner beliefs and study abroad: A study on English as a lingua franca (ELF). System, 42355367. https://doi.org/10.1016/j.system.2014. (14.05.2019).

Kegan, R. 1982. The evolving: Problem and process in human development. Cambridge, MA: Harvard University Press.

Kennworthy, J., Turner, R., Hewstone, M. and Voci, A. 2005. Intergroup Contact: When Does It Work, and Why? In: Dovidio, J.F., Glick, P. and Rudman, L. eds. On the Nature of Prejudice. Oxford: Blackwell, pp. 278-292. 
King, P. and Kitchener, K. 2002. The reflective judgment model: Twenty years of research on epistemic cognition. In: Hofer, B. and Pintrich, P. eds. Personal epistemology: The psychology of beliefs about knowledge and knowing. Mahway, NJ: Lawrence Erlbaum, Publisher, pp. 37-61.

King, P. and Kitchener, K. 2004. Reflective Judgment: Theory and Research on the Development of Epistemic Assumptions Through Adulthood. Educational Psychologist. 39 (1), pp. 5-18.

King, P., Kitchener, K., Davison, M., Parker, C. and Wood, P. 1983. The justification of beliefs in young adults: A longitudinal study. Human Development. 26, pp. 106-116.

King, P., Kitchener, K. and Wood, P. 1994. Research on the reflective judgment model. Developing reflective judgment: Understanding and promoting intellectual growth and critical thinking in adolescents and adults. San Francisco: Jossey-Bass.

King, P., Wood, P. and Mines, R. 1990. Critical Thinking Among College and Graduate Students. The Review of Higher Education. 13 (2), pp. 167-186. Kitchener, K., Lynch, C., Fischer, K. and Wood, P. 1993. Developmental range of reflective Judgment: The effect of contextual support and practice on developmental stage. Developmental Psychology. 29, pp. 893-906.

Kitchener, K. and King, P. 1981. Reflective judgment: Concepts of justification and their relationship to age and education. Journal of Applied Developmental Psychology. 2, pp. 89-116.

Kitchener, K., King, P. and DeLuca, S. 2006. Development of Reflective Judgment in Adulthood. In: Hoare, C. ed. Handbook of Adult Development and Learning. New York: Oxford University Press, pp. 73-98.

Llanes, À., Arnó, E. and Mancho-Barés, G. 2016. Erasmus students using English as a lingua franca: does study abroad in a non-English-speaking country improve L2 English? The Language Learning Journal. 44 (3), pp. 292-303.

Maiworm, F. and Teichler, U. 2002. The Students' Experience. In: Teichler, U. ed. Erasmus in the Socrates Programme. Bonn: Lemmens, pp. 83-115.

Murphy-Lejeune, E. 2002. Student Mobility and Narrative in Europe: The New Strangers. London: Routledge.

Odrowąż-Coates, A. 2017. Przekonania studentów pedagogiki w pryzmacie dominującej formacji światopoglądowej. Edukacja Międzykulturowa. 2 (7), pp. 225-239.

Odrowąż-Coates, A. 2019. Socio-educational Factors and the Soft Power of Language: The Deluge of English in Poland and Portugal. Lanham, New York: Lexington Books, Rowman \& Littlefield. 
Odrowąż-Coates, A. and Perkowska-Klejman, A. 2017. A preliminary study of Polish students' aptitude for thinking reflexively, differentiated by higher education faculties and the level of study. Society Register. 1 (1), pp. 97-106. OECD 2005. The definition and selection of key competencies. https://www. oecd.(21.10.2019).

Perkowska-Klejman, A. 2014. Osądzanie refleksyjne - ocena intelektualnego rozwoju uczniów, studentów i absolwentów. Ruch Pedagogiczny. 4, pp. 69-84 .

Perkowska-Klejman, A. 2018. Jak rozwiązywać trudne poznawczo problemy? - refleksyjność studentów programu Erasmus. Pedagogika Szkoty Wyższej. 1, pp. 55-70.

Perkowska-Klejman, A. and Odrowąż-Coates, A. 2019. Measuring the unmeasurable? Differences in reflexive thinking amongst polish students, The New Educational Review. 55 (1), pp. 77-88.

Perry, W. 1981. Cognitive and Ethical Growth: The Making of Meaning. In: Chickering, A.W. ed. The Modern American College. San Francisco: Jossey-Bass, pp. 76-116.

Pettigrew, T.F. 1998. Intergroup Contact Theory. Annual Review of Psychology. 49, pp. 65-85.

Serrano, R., Llanes, À. and Tragant, E. 2011. Analyzing the effect of context of second language learning: Domestic intensive and semi-intensive courses vs. study abroad in Europe. System. 39 (2), pp. 133-143,

Stangor, C., Jonas, K., Stroebe, W. and Hewstone, M. 1996. Influence of Student Exchange on National Stereotypes, Attitudes and Perceived Group Variability. European Journal of Social Psychology. 26 (4), pp. 663-675.

Stroebe, W., Lenkert., A. and Jonas, K. 1988. Familiarity May Breed Contempt: The Impact of Student Exchange on National Stereotypes and Attitudes. In: Stroebe, W., Kruglanski, A., Bar-Tal, D. and Hewstone, M. eds. The Social Psychology of Intergroup Conflict. London: Springer-Verlag, pp. 167$-187$.

Szubert, T. 2013. Program Erasmus w opinii polskich studentów. Warszawa: Fundacja Rozwoju Systemu Edukacji.

Ścigała, O. 2014. Pokolenie Erasmusa - przykład tożsamości europejskiej w praktyce? In: Osiński, J. and Popławska, Z. eds. Oblicza społeczeństwa obywatelskiego. Warszawa: Oficyna Wydawnicza SGH.

Teichler, U. 2002. Erasmus in the Socrates Programme. Bonn: Lemmens. Tullock, B. and Ortega, L. 2017. Fluency and multilingualism in study abroad: Lessons from a scoping review. System. 71, pp. 7-21. 
Van Tine, N.B. 1990. The development of reflective judgment in adolescents. Dissertation Abstracts International. 51, pp. 26-59.

Walczak, D. 2017. Za i przeciw międzynarodowej mobilności studentów i naukowców. In: Siemieńska, R. ed. Uniwersytety, naukowcy i studenci w zglobalizowanym świecie. Warszawa: Scholar, pp. 123-144.

Ward, C., Bochner, S. and Furnham, A. 2001. The psychology of culture shock. Hove: Routledge.

Wood, P. and Kardash, C. 2002. Critical elements in the design and analysis of studies of epistemology. In: Hofer, B.K. and Pintrich, P.R. eds. Personal epistemology: The psychology of beliefs about knowledge and knowing. Mahwah, NJ, US: Lawrence Erlbaum Associates Publishers, pp. 231-260. 